\title{
Research and development accounting treatment: effects of CEO characteristics and corporate governance mechanisms
}

\author{
Sana Triki Damak * \\ PhD in Accounting, Department of Accounting in Institute of High Business Studies of Sfax, Sfax University, Tunisia \\ *Corresponding author E-mail: sanatriki@ hexabyte.tn
}

\begin{abstract}
This study aims to examine empirically the influence of Chief Executive Officer (CEO) characteristics and corporate governance mechanisms on Research and Development (R\&D) capitalization in France.

Using data drawn from a sample of non-financial firms listed in SBF 120, this study provides empirical evidence for the influence of CEO characteristics and audit quality on R\&D capitalization. As results, we find that R\&D capitalization is likely to be increased in firms managed by younger managers, CEOs with higher ownership, shorter tenure and higher educational level. Also, R\&D capitalization is likely to be increased in firms with lower audit quality, in higher leveraged firms, in less performed and larger firms. This study offers insights to investors and accounting standard setters interested about the subject of R\&D capitalization determinants Importantly, it confirms that some CEO characteristics and corporate governance mechanisms are likely to affect the CEO's behavior regarding the $\mathrm{R} \& \mathrm{D}$ accounting treatment.
\end{abstract}

Keywords: CEO Characteristics; Corporate Governance; R\&D; France.

\section{Introduction}

Accounting policies and their roles in management's external reporting strategy are central issues in financial reporting. Murphy et al. (2013) focus on the importance of the social role of accounting in spite of the formal pronouncements of standard setters. The manager has been and continues to be integrated into the living law of accounting despite official pronouncements of standardization. Indeed, the manager strategically intervenes in the financial reporting process to overcome the firm control systems and to maximize private benefits. He takes advantage of the specific nature of certain expenditures like those related to $R \& D$. These expenditures are considered to be an important source of agency problems between managers and stakeholders.

Over the last years, R\&D accounting choices determinants have attracted a great deal of attention among researchers and accounting standard setters since these expenditures are exposed to a high level of uncertainty and information asymmetry.

R\&D expenditures are subject to managerial discretion and could lead to many accounting manipulations (Chambers et al. 2003, Nekhili \& Rebai Azouz 2006). Also, capitalization dominates signaling effects of discretionary R\&D accounting treatment (Thi \& Schultze 2014, Dinh et al. 2016). Prior literature finds significant discretion in choosing the accounting method for R\&D expenditures (Chambers et al. 2003, Markarian et al. 2008, Oswald 2008, Banal-Estañol \& Macho-Stadler 2010, Dinh et al. 2016). According to Dong and Gou (2010), discretionary power of managers is affected by three factors: governance structure, management structure and manager characteristics.

This research focuses on the relationship between managerial variables and $R \& D$ accounting treatment. Based on the agency theory, the entrenchment perspective and the signaling theory, we try to answer to the following question. How do CEO characteristics affect R\&D accounting treatment?

Furthermore, this study evaluates the influence of some corporate governance variables on the R\&D capitalization. Better governance can reduce opportunistic behavior in financial reporting (Klein 2002, Liao 2011). By considering corporate governance attributes, we could assess their influence on the R\&D capitalization. Indeed, many studies find significant relationships between corporate governance and R\&D voluntary disclosure (Zéghal et al. 2007, Nor et al. 2010, Nekhili et al. 2016).

To address these issues, this research considers the French context. We propose an original empirical study, regarding the characteristics of the French context, which offers a setting marked by the predominant role of CEOs and strong managerial networks (Chikh \& Filbien 2011). Moreover, the French regulatory framework in accounting for R\&D expenditures has survived many changes, both in financial statements and consolidated accounts. French accounting regulation since CRC 04-06 has largely been closed to the international standards. Indeed, the distinction between basic research, applied research and development (which existed in the General Accounting Plan 1999) is abandoned in favour of only two phases, a research phase and a development phase. However, even if the recognition of development costs as an asset is considered to be the preferred method by the CRC rule 2004-06, it appears as a mandatory method under IAS 38 if the capitalization criteria are met.

Since 2005, all French listed companies have been obliged to prepare their annual reports in accordance with international standards (IFRS/IAS); and then to apply the IAS 38. Despite the obligation that seems to characterize IAS 38 if the conditions of capitalization of R\&D expenditures are satisfied, prior literature show that actual R\&D capitalization, under IAS 38, depends on earnings 
management purposes (Triki Damak \& Halioui 2013) and doesn't reduce information asymmetries (Thi \& Schultze 2014).

This research provides a better understanding of the role played by CEOs behavior and corporate governance mechanisms in the $\mathrm{R} \& \mathrm{D}$ accounting treatment issue; and then provides several contributions to both academia and practice.

First, it offers new evidence for the managerial literature by investigating the associations between CEO characteristics and R\&D financial accounting report. To the best of our knowledge, this is the first study to examine the relationship between the CEO characteristics and the R\&D accounting treatment.

Second, the fact of considering several corporate governance attributes, like the board characteristics and the external audit quality, makes the research coherent and consistent.

Finally, accounting standard setters and regulators are likely to be interested in R\&D accounting decisions determinants. A central issue in the $R \& D$ accounting treatment debate is whether managers should have or not the flexibility to capitalize certain R\&D expenditures.

Then, this paper is organized as follows. The theoretical background and the developed hypotheses are set out in Section 2, while Section 3 explains the research design. Section 4 presents the results. Concluding remarks are summarized in Section 5.

\section{Literature and hypotheses development}

Managers' beneficiaries of informational rent can enjoy the flexibility of R\&D accounting treatment to overcome the control systems putted by the shareholders or other stakeholders of the firm. The manipulation of $R \& D$ accounting treatment is one of the most important policies that could be used by managers to reach their objectives seen the complexity of R\&D accounting treatment decision. Then, it is interesting to investigate how the managers' characteristics affect the R\&D accounting treatment. Also, it is important to assess the role of corporate governance variables.

\subsection{CEO characteristics}

Prior literature classified CEO power into ownership, expertise and prestige power (Finkelstein 1992, Chikh \& Filbien 2011). The expertise power refers to CEO age and tenure. The prestige power could be given through CEO education.

\subsubsection{CEO age}

The psychological literature provides evidence that old and young managers have different attitudes toward their commitment to the company (Williams \& Hazer 1986). Age is likely to be an influential factor in top managers' decisions.

By their nature, R\&D investments are risky (Miller \& Bromiley 1990) and prior studies confirm that older managers prefer prudent and conservative accounting practices (Sundaram \& Yermack 2007, Huang et al. 2012). So, it is expected that older managers prefer the expense of R\&D expenditures.

On the other side; and based on the signaling theory, younger managers need to develop their image in the labour market. Seen, the informative nature of R\&D capitalization (Chambers et al 2003, Healy et al. 2002, Zhao 2002, Oswald 2008), we estimate that younger managers prefer the R\&D capitalization to divulgate their innovation efforts and signal to investors their capacities to conduct $R \& D$ projects. So, it is expected a negative relationship between the CEO age and the R\&D capitalization.

Hypothesis 1. There exists a negative relationship between the $R \& D$ capitalization and the CEO age.

\subsubsection{CEO tenure}

Based on the entrenchment theory, longer tenure is usually associated with manager stronger power. Matsunaga and Yeung (2008) find that CEO's expertise influence significantly the firm's discretionary accruals. The expertise power affects particular managerial strategic decision making (Finkelstein 1992). Indeed, CEO incentives to manage earnings change with his tenure in the firm (Ali \& Zhang 2015).

At the beginning of his career in the firm, the manager tries to use accounting methods, which increase the firm's earnings, like the R\&D capitalization. Earnings are more likely to be overstated in the early years than in the later years of the CEO's service (Ali \& Zhang 2015). So, it is expected that the manager prefers the $R \& D$ capitalization at the beginning of his career in the firm. Moreover, the investors appreciate the R\&D disclosure efforts made by managers (Nekhili et al. 2016). The manager wants to show his interest for the company's growth. He highlights the R\&D investments to prove that he is motivated to enhance the long term performance of the firm. When he keeps his position for a long time, the manager behavior turns into defensive entrenchment (Pigé 1998, Paquerot 1997). To make his replacement difficult, the manager favors an increase in information asymmetry (Vernimmen et al. 2014) and adopts the accounting policies, which hide the firm's key strategies, like expensing R\&D investments. So, it is expected a negative relationship between the CEO tenure and the R\&D capitalization.

Hypothesis 2. There exists a negative relationship between the R\&D capitalization and the CEO tenure.

\subsubsection{CEO ownership}

According to agency perspective, the separation of ownership and control leads to a potential conflict of interests. One way to align manager personal interests with shareholders is to grant him stock options (Jensen \& Murphy 2010, Wu \& Tu 2007). However, the CEO participation in the capital may affect the firm accounting policies. Indeed, managers usually hold their shares in a short period (Nekhili \& Poincelot 2000). It is therefore expected that managers choose accounting methods that lead to maximize the firm's short-term profit. The R\&D capitalization could be one of these accounting policies.

Moreover, Warfield et al. (1995) offer evidence on the positive relationship between accounting informativeness and managerial ownership. The capitalization of R\&D is informative due to its signaling effects (Thi \& Schultze 2014). So, it is expected a positive relationship between the R\&D capitalization and the CEO ownership.

Hypothesis 3. There exists a positive relationship between the $\mathrm{R} \& \mathrm{D}$ capitalization and the CEO ownership.

\subsubsection{CEO Education}

Prestige power, related to the social networks that CEOs obtain from their former education, plays a considerable role in the firm accounting practices. The relational network and the competence of a CEO graduated from prestigious institution are success keys to satisfy the most challenging condition of $R \& D$ capitalization which is: "The availability of adequate technical, financial and other resources to complete the development and to use or sell the intangible asset" (IASB 2009). The French CEO market is characterized by two managerial elites, namely, CEOs from the École Nationale d'Administration (ENA) and the Polytechnique (Dameron 2008, Chikh \& Filbien 2011, Triki Damak \& Halioui 2016). These two elites are known by their overconfidence, which affects financial reporting behavior (Schrand \& Zechman 2012). They are usually in competition and try to divulgate their innovation capacities.

The literature provides some empirical evidence for the negative relationship between $\mathrm{CEO}$ overconfidence and accounting conservatism (Schrand \& Zechman 2012, Anwer \& Scott 2013). Confident manager is sure for his ability to succeed innovation projects. He considers that his $R \& D$ expenditures are generating positive outcomes (Koh et al. 2015). Then, a confident manager is encouraged to disclose the firm's R\&D investments (Koh et al. 2015).

Seen his competence, relational network and self-confidence, the manager graduated from prestigious institution prefers probably 
the R\&D capitalization. So, it is expected a positive relationship between the R\&D capitalization and the CEO former education in a prestigious institution

Hypothesis 4. There exists a positive relationship between the $R \& D$ capitalization and the CEO education in a prestigious institution.

\subsection{Corporate governance variables}

To perfect the analysis, it is interesting to assess the role of corporate governance variables in the $\mathrm{R} \& \mathrm{D}$ accounting treatment issue Garcia Lara et al. (2009) confirm that stronger corporate governance will present a higher degree of accounting conservatism. However, Chi and Hsu (2009) confirm that firms with weaker governance structures tend to be more conservative.

A stronger governance structure is usually characterized by an independent board of directors, a separation of the CEO position from the chair of the board position and a high external audit quality.

It is important to understand whether these mechanisms could motivate managers to increase or decrease the $R \& D$ capitalization.

\subsubsection{Board of directors independence}

The board of directors is responsible for evaluating, disciplining the management of a company and monitoring the quality of information disclosed in financial reports (Anderson et al., 2004 Holtz \& Neto 2014). The board's independence is an aspect associated with a higher quality of accounting information (Marra et al 2011). Indeed, the manager should justify the heavy expenditures of the firm, like those of $R \& D$, since external directors have less specific knowledge about the firm's activities (Kim et al. 2014) Prior literature finds significant relationships between the board's compositional characteristics and the reported accounting information (Forker 1992, Arcay \& Vázquez 2005, Dimitropoulos \& Asteriou 2010, Abdoli \& Royaee 2012, Holtz \& Neto 2014). This literature shows the positive relationship between the percentage of independent directors and accounting earnings informativeness. Also, prior studies confirm that R\&D capitalization improves accounting informativeness (Chambers et al. 2003, Healy et al 2002, Zhao 2002, Oswald 2008). So, it is expected a positive relationship between the R\&D capitalization and the board of directors' independence.

Hypothesis 5. There exists a positive relationship between the R\&D capitalization and the board of directors' independence.

\subsubsection{CEO duality of roles}

The separation of the chairman and CEO roles is presented as a means of ensuring the balance of power, increasing the capacity of the board to responsible the manager and to provide a better communication of financial and accounting information (Nekhili \& Fakhfakh 2006). The practice of separating the CEO and board chair positions obliges the manager to well justify all the important firm expenditures like those of R\&D. So, the firms adopting the CEO duality of functions have a lower level of financial disclosure (Ho \& Wong 2001, Gul \& Leung 2004). The capitalization is the best way to disclose R\&D investments (Rebai Azouz 2011). So, the R\&D capitalization is likely to be decreased in the cases of CEO duality of roles. Also, prior literature confirms the negative relationship between the CEO duality of roles and the quality of accounting information (Lara et al. 2007, Firth et al 2007). Seen the informativeness nature of $R \& D$ capitalization (Chambers et al. 2003, Healy et al. 2002, Zhao 2002, Oswald 2008), it is expected a negative relationship between the R\&D capitalization and the CEO duality of roles.

Hypothesis 6. There exists a negative relationship between the $\mathrm{R} \& \mathrm{D}$ capitalization and the CEO duality of roles.

\subsubsection{External audit quality}

High-quality external auditing helps to reduce the information asymmetry between managers and investors and to resolve agency conflicts. It often contributes to a lower earnings management (Ben Othmen \& Zéghal 2006). The need of stakeholders to be confident of audit quality remains one of the keys to effective firm supervision. Regarding the impact of audit quality on the accounting practices for intangible investments, prior research has led to different results. Chi and Weng (2014) confirm that the auditors "big four" prefer prudent accounting choices for their clients like the expense of R\&D expenditures. However, Tutticci et al. (2007) show the positive effect of external audit quality on the level of R\&D capitalization. Similarly, Bourmont (2006) confirms the positive effect of audit quality on the level of R\&D voluntary disclosure. Well reputed auditors encourage their customers to be transparent and to disclose their spending (Bourmont 2006). Also, these auditors are careful to be adapted to the new request of financial information users who intensively ask for information about the firm creators of value such as: intellectual capital, patents, human resources, R\&D investments (Bertin 2002). Therefore, it's expected a positive relationship between the R\&D capitalization and the external audit quality.

Hypothesis 7. There exists a positive relationship between the R\&D capitalization and the external audit quality

\subsection{Control variables}

Some control variables are associated to independent variables to illustrate their moderating effects on $\mathrm{R} \& \mathrm{D}$ capitalization: the past performance, the leverage and the size.

\subsubsection{Past Performance}

By achieving a good past performance, managers, having won the confidence of shareholders, tend to decrease the current results of the firm. Indeed, taking advantage of this opportunity and as part of their entrenchment strategy; the managers try to not reveal their specific investments such as R\&D. So, they prefer to expense $\mathrm{R} \& \mathrm{D}$ investments. However, the bad past performance encourages the manager to capitalize the R\&D expenditures in order to increase the current results and to report to the shareholders a good future performance of the company.

\subsubsection{Leverage}

Managers are encouraged to take advantage of the accounting standards flexibility to not exceed the restrictive covenants imposed by debt contracts (De Fond \& Jiambalvo 1994). According to Bétriou and Vignolles (1990) and Aboody and Lev (1998), the $\mathrm{R} \& \mathrm{D}$ capitalization decreases the debt ratio which encourages the managers of highly leveraged firms to opt for the capitalization rather than the expense. The positive impact of leverage on the R\&D capitalization has been demonstrated in prior research (Landry \& Callimaci 2003, Markarian et al. 2008, Cazavan-Jeny et al. 2011, Triki Damak \& Halioui 2013).

\subsubsection{Size}

The political visibility of the company measured by its size (Ben Othman \& Zéghal 2006) encourages big firms to select accounting options that decline profits. Then, the managers of big firms tend to expense R\&D expenditures (Cazavan-Jeny et al. 2011). Prior research confirms the negative influence of the firm size on the R\&D capitalization (Percy 2000, Cazavan-Jeny et al. 2011). 


\section{Research design}

\subsection{Models}

To test the relationship between $R \& D$ capitalization and CEO characteristics, the first model is estimated.

\section{Model 1:}

R\&D_CAP ${ }_{i t}=\alpha_{0}+\alpha_{1}$ CEO AGE $_{i t}+\alpha_{2}$ CEO TENURE $_{i t}+$ $\alpha_{3}$ CEO OWN ${ }_{i t}+\alpha_{4}$ CEO EDUC $_{i t}+\alpha_{5}$ PAST PERF $_{\text {it }}+\alpha_{6}$ LEV $_{\text {it }}+$ $\alpha_{7} \mathrm{SIZE}_{\mathrm{it}}+\mathrm{u}_{\mathrm{it}}$

In the second model, some corporate governance variables are added to test the simultaneous effect of CEO characteristics and corporate governance variables on $\mathrm{R} \& \mathrm{D}$ capitalization.
Model 2:

R\&D_CAP it $=\alpha_{0}+\alpha_{1}$ CEO AGE it $+\alpha_{2}$ CEO TENURE $_{i t}+$ $\alpha_{3}$ CEO OWN $_{\text {it }}+\alpha_{4}$ CEO EDUC $_{\text {it }}+\alpha_{5}$ BOARD INDEP $_{\text {it }}+$ $\alpha_{6}$ CEO DUAL $_{i t}+\alpha_{7}$ AUDIT QUAL $_{i t}+\alpha_{8}$ PAST PERF $_{\text {it }}+$ $\alpha_{9} \mathrm{LEV}_{\text {it }}+\alpha_{10} \mathrm{SIZE}_{\mathrm{it}}+\mathrm{u}_{\mathrm{it}}$

\subsection{Empirical measures}

Table 1 presents all measures of variables included in the models.

\subsection{Data}

To carry out this research, we use a sample of French listed companies belonging to the SBF 120 index during all the study period (2003-2011). After eliminating the financial specialized businesses (insurances and banks), the companies with no complete accounting and financial information necessary to our conduct study, only 35 firms are effective. Then, we obtained a final sample of 35 companies observed over 9 years, that is to say 315 observations.

Table 1: Variables Definitions

\begin{tabular}{|c|c|c|}
\hline Variables & Definition & Measurement \\
\hline \multicolumn{3}{|c|}{ Dependent variable } \\
\hline R\&D_CAP & $\begin{array}{l}\text { R\&D } \\
\text { capitaliza- } \\
\text { tion }\end{array}$ & $\begin{array}{l}\text { Is measured as the ratio of company's R\&D capitalized expenditures to total R\&D expenditures (PricewaterhouseCoopers } \\
\text { 2010, Dumas 2013). }\end{array}$ \\
\hline \multicolumn{3}{|c|}{ Independent variables } \\
\hline CEO AGE & CEO's age & Is the age of the CEO in years (Mouline 2000, Barker \& Mueller 2002, Ghosh et al. 2007). \\
\hline CEO OWN & $\begin{array}{l}\text { CEO’s } \\
\text { Ownership }\end{array}$ & Is measured as the percentage of shares held by the top manager (Klein 2002, Dong \& Gou 2010). \\
\hline $\begin{array}{l}\text { CEO } \\
\text { EDUC }\end{array}$ & $\begin{array}{l}\text { CEO's } \\
\text { Education }\end{array}$ & $\begin{array}{l}\text { Is a dummy variable coded } 1 \text { if the top manager is graduated from the Polytechnique or ENA and } 0 \text { otherwise (Elaouadi 2001, } \\
\text { Chikh \& Filbien 2011, Triki Damak \& Halioui 2016). }\end{array}$ \\
\hline $\begin{array}{l}\text { BOARD } \\
\text { INDEP }\end{array}$ & $\begin{array}{l}\text { Board } \\
\text { independ- } \\
\text { ence }\end{array}$ & $\begin{array}{l}\text { Is measured as the number of independent outside directors in the board divided by the total number of directors in the board } \\
\text { (Dong \& Gou 2010, Nekhili et al. 2016). }\end{array}$ \\
\hline $\begin{array}{l}\text { AUDIT } \\
\text { QUAL }\end{array}$ & Audit quality & $\begin{array}{l}\text { Is a dummy variable coded } 1 \text { if the firm is co-audited by two big and } 0 \text { otherwise (Benali 2013, Triki Damak \& Halioui } \\
\text { 2016). }\end{array}$ \\
\hline \multicolumn{3}{|c|}{ Control variables } \\
\hline $\begin{array}{l}\text { PAST } \\
\text { PERF }\end{array}$ & $\begin{array}{l}\text { The Past } \\
\text { Performance }\end{array}$ & Is measured as the ratio of operating income to total assets (Barker \& Muller 2002, Chen \& Hsu 2009). \\
\hline LEV & $\begin{array}{l}\text { The firm's } \\
\text { leverage }\end{array}$ & $\begin{array}{l}\text { Is measured as the ratio total liabilities to total assets (Markarian et al. 2008, Garcia Lara et al. 2009, Kamarudin et al. } 2012 \text {, } \\
\text { Jedidi Hentati \& Jilani 2013, Triki Damak \& Halioui 2013, Nekhili et al. 2016). }\end{array}$ \\
\hline SIZE & $\begin{array}{l}\text { The firm's } \\
\text { size }\end{array}$ & $\begin{array}{l}\text { Is measured as the logarithm of total assets (Cormier et al. 1998, Markarian et al. 2008, Kamarudin et al. 2012, Triki Damak } \\
\& \text { Halioui 2013, Nekhili et al. 2016). }\end{array}$ \\
\hline
\end{tabular}

Table 2 presents the industry distribution of the sample.

Table 2: Industry Distribution of the Sample

\begin{tabular}{|c|c|c|c|c|}
\hline Sectors & Industries of high technology & Traditional industries & Services sector & Total \\
\hline \multicolumn{5}{|l|}{ Years } \\
\hline 2003 & 19 & 11 & 5 & 35 \\
\hline 2004 & 19 & 11 & 5 & 35 \\
\hline 2006 & 19 & 11 & 5 & 35 \\
\hline 2007 & 19 & 11 & 5 & 35 \\
\hline 2008 & 19 & 11 & 5 & 35 \\
\hline 2009 & 19 & 11 & 5 & 35 \\
\hline 2010 & 19 & 11 & 5 & 35 \\
\hline 2011 & 19 & 11 & 5 & 35 \\
\hline Total & 171 & 99 & 45 & 315 \\
\hline
\end{tabular}

Data were collected from different sources which are presented in table 3. 
Table 3: Data Sources

\begin{tabular}{lll}
\hline Variables & Required data & Sources of information \\
\hline Dependent variables & Firms annual reports, scoreboard prepared by the European Re- \\
R\&D_CAP & R\&D capitalized expenditures and total R\&D expenditures & search Commission \\
Independent variables & \\
Test variables & & Firms websites and annual reports \\
CEO AGE & The age of the top manager & Firms websites and annual reports \\
CEO TENURE & The number of years in the post of manager & Firms annual reports \\
CEO OWN & The shares held by the top manager and the total of shares & Firms websites and annual reports \\
CEO EDUC & The graduation of the top manager & Firms annual reports \\
BOARD IN- & The number of independent directors in the board and the total & Firms annual reports \\
DEP & number of directors & Firms annual reports \\
CEO DUAL & The CEO and the chairman of the board of directors & \\
AUDIT QUAL & The external auditors & Datastream \\
Control variables & & Datastream \\
PAST PERF & Operating income and total assets & Datastream \\
LEV & Total liabilities and total assets & \\
SIZE & Total assets &
\end{tabular}

\section{Empirical results}

Descriptive statistics for all variables are presented in table 4 .

This table presents the univariate statistics related to the variables that describe the CEO characteristics, corporate governance and control variables. Findings show a significant disparity in the percentage of capitalized $R \& D$ expenditures demonstrated by the remarkable difference between the minimum $(0 \%)$ and the maximum $(71,6 \%)$. Also, the table reveals that, in the average, firms capitalize $9,3 \%$ of their total R\&D expenditures.

Descriptive statistics show, in regard of the CEO characteristics, that the average age of managers is over 55 years and the average tenure is less than 7 years. Moreover, as shown in table 4, the average of managerial ownership is $0,14 \%$; and finally $46 \%$ of managers are graduates from French elite schools.

Regarding the corporate governance variables, the table 4 shows that more than half of the cases have independent directors and in more than $70 \%$ of the cases, the CEO is chairman of the board.
Also, the descriptive statistics show that more than half of the cases are jointly co-audited by two "BIG".

The results of the normality tests are presented in table 5 .

The findings show that the majority of independent variables don't follow the normal distribution. Then, it is suitable to use the nonparametric test "Mann-Whitney".

Table 6 synthesizes the results of Mann-Whitney test.

The Mann-Whitney test confirms a strong relationship between R\&D capitalization and CEO ownership. Moreover, it appears a significant relationship between R\&D capitalization and CEO education.

Concerning corporate governance variables, we observe significant relationship between R\&D capitalization and audit quality.

Finally, the control variables show a significant influence of past performance, leverage and size on R\&D capitalization.

The correlations between the independent variables and Variance Inflation Factor (VIF) coefficients are presented in table 7.

Table 4: Descriptive Statistics

\begin{tabular}{|c|c|c|c|c|c|c|}
\hline \multicolumn{7}{|c|}{ Continuous Variables } \\
\hline & Min & Max & Mean & & Median & Std \\
\hline CAP_R\&D & 0,0000 & 0,7156 & 0,0926 & & 0,0000 & 0,1565 \\
\hline CEO AGE & 34,0000 & 73,0000 & 55,1015 & & 55,0000 & 7,4446 \\
\hline CEO OWN & 0,0000 & 0,0708 & 0,0014 & & 0,0000 & 0,0060 \\
\hline BOARD INDEP & 0,0000 & 0,9000 & 0,5022 & & 0,5384 & 0,1869 \\
\hline PAST PERF & $-0,6717$ & 0,3375 & 0,0655 & & 0,0711 & 0,0932 \\
\hline LEV & 0,0000 & 0,7199 & 0,2284 & & 0,2165 & 0,1387 \\
\hline SIZE & 10,8309 & 18,4038 & 15,7656 & & 15,7493 & 1,5311 \\
\hline \multicolumn{7}{|c|}{ Dichotomous variables } \\
\hline \multirow{4}{*}{ CEO EDUC } & \multicolumn{3}{|c|}{ Frequency } & \multicolumn{2}{|l|}{ Percent } & Cum \\
\hline & 0 & \multicolumn{2}{|c|}{170} & \multicolumn{2}{|l|}{53,97} & 53,97 \\
\hline & 1 & \multicolumn{2}{|c|}{145} & \multicolumn{2}{|l|}{46,03} & 100 \\
\hline & Total & \multicolumn{2}{|c|}{315} & \multicolumn{2}{|l|}{100} & \\
\hline \multirow{3}{*}{ CEO DUAL } & 0 & \multicolumn{2}{|c|}{87} & \multicolumn{2}{|l|}{27,62} & 27,62 \\
\hline & 1 & \multicolumn{2}{|c|}{228} & \multicolumn{2}{|l|}{72,38} & 100.00 \\
\hline & Total & \multicolumn{2}{|c|}{315} & \multicolumn{2}{|l|}{100.00} & \\
\hline \multirow{2}{*}{ AUDIT QUAL } & 1 & \multicolumn{2}{|c|}{168} & \multicolumn{2}{|l|}{53,33} & 100 \\
\hline & Total & \multicolumn{2}{|c|}{315} & \multicolumn{2}{|l|}{100} & \\
\hline \multicolumn{7}{|c|}{ Table 5: Normality Test for Independent Variables } \\
\hline Variables & Pr (Skeweness) & \multicolumn{2}{|c|}{ Pr (kurtosis) } & \multicolumn{2}{|c|}{ Adj Chi2(2) } & Prob>Chi2 \\
\hline CEO AGE & 0,2083 & & & 1,6 & & 0,4484 \\
\hline CEO TENURE & 0 & & & 56,19 & & 0 \\
\hline CEO OWN & 0 & 0 & & . & & 0 \\
\hline BOARD INDEP & 0,0017 & & & 9,69 & & 0,0079 \\
\hline PAST PERF & 0 & 0 & & . & & 0 \\
\hline LEV & 0,0002 & & & 13,02 & & 0,0015 \\
\hline SIZE & 0,0048 & & & 8,51 & & 0,0142 \\
\hline
\end{tabular}


Table 6: Mann-Whitney Test

\begin{tabular}{|c|c|c|c|c|c|c|}
\hline & Model 1 & & & Model 2 & & \\
\hline & CAP_R\&D & & & CAP_R\&D & & \\
\hline & G1 & G2 & $\begin{array}{l}\mathrm{Z} \\
\text { (p-value) }\end{array}$ & G1 & G2 & $\begin{array}{l}\mathrm{Z} \\
\text { (p-value) }\end{array}$ \\
\hline CEO AGE & 26306 & 23464 & $\begin{array}{l}-0,787 \\
(0,4311)\end{array}$ & 26306 & 23464 & $\begin{array}{l}-0,787 \\
(0,4311)\end{array}$ \\
\hline CEO TENURE & 28914,5 & 20855,5 & $\begin{array}{l}0,227 \\
(0,8202)\end{array}$ & 28914,5 & 20855,5 & $\begin{array}{l}0,227 \\
(0,8202)\end{array}$ \\
\hline CEO OWN & 20764 & 29006 & $\begin{array}{l}-5,950 * * * \\
(0,000)\end{array}$ & 20764 & 29006 & $\begin{array}{l}-5,950 * * * \\
(0,000)\end{array}$ \\
\hline CEO EDUC & 24191,5 & 25578,5 & $\begin{array}{l}-3,792 * * * \\
(0,0001)\end{array}$ & 24191,5 & 25578,5 & $\begin{array}{l}-3,792 * * * \\
(0,0001)\end{array}$ \\
\hline POAPD INDFP & & & & 24740 & 25030 & 0,354 \\
\hline CEO DUAL & & & & 13899 & 35926 & $\begin{array}{l}0,155 \\
(0,8766)\end{array}$ \\
\hline AUDIT QUAL & & & & 25052 & 29718 & $\begin{array}{l}2,593 * * * \\
(0,0095)\end{array}$ \\
\hline PAST PERF & 26805 & 22965 & $\begin{array}{l}2,832 * * * \\
(0,0046)\end{array}$ & 26805 & 22965 & $\begin{array}{l}2,832 * * * \\
(0,0046)\end{array}$ \\
\hline LEV & 10493 & 39277 & $\begin{array}{l}-4,451 * * * \\
(0,000)\end{array}$ & 10493 & 39277 & $\begin{array}{l}-4,451 * * * \\
(0,000)\end{array}$ \\
\hline SIZE & 22723 & 27047 & $\begin{array}{l}-3,175 * * * \\
(0,0015)\end{array}$ & 22723 & 27047 & $\begin{array}{l}-3,175 * * * \\
(0,0015)\end{array}$ \\
\hline
\end{tabular}

${ }^{*} \mathrm{p}<0,10 ; * * \mathrm{p}<0,05 ; * * * \mathrm{p}<0,01$.

Table 7: Spearman correlation Matrix and VIF

\begin{tabular}{|c|c|c|c|c|c|c|c|c|c|c|c|c|}
\hline & $\begin{array}{l}\text { CEO } \\
\text { AGE }\end{array}$ & $\begin{array}{l}\text { CEO } \\
\text { TENURE }\end{array}$ & $\begin{array}{l}\text { CEO } \\
\text { OWN }\end{array}$ & $\begin{array}{l}\text { CEO } \\
\text { EDUC }\end{array}$ & $\begin{array}{l}\text { BOARD } \\
\text { INDEP }\end{array}$ & $\begin{array}{l}\text { CEO } \\
\text { DUAL }\end{array}$ & $\begin{array}{l}\text { AUDIT } \\
\text { QUAL }\end{array}$ & $\begin{array}{l}\text { PAST } \\
\text { PERF }\end{array}$ & LEV & SIZE & VIF1 & VIF2 \\
\hline CEO AGE & 1,000 & & & & & & & & & & 1,20 & 1,32 \\
\hline CEO TENURE & 0,283 & 1,000 & & & & & & & & & 1,16 & 1,19 \\
\hline CEO OWN & $-0,101$ & $-0,084$ & 1,000 & & & & & & & & 1,04 & 1,05 \\
\hline CEO EDUC & $-0,031$ & $-0,009$ & $-0,034$ & 1,000 & & & & & & & 1,21 & 1,25 \\
\hline BOARD INDEP & $-0,106$ & $-0,018$ & 0,142 & $-0,041$ & 1,000 & & & & & & - & 1,06 \\
\hline CEO DUAL & 0,263 & 0,085 & $-0,096$ & 0,043 & $-0,075$ & 1,000 & & & & & - & 1,12 \\
\hline AUDIT QUAL & 0,009 & $-0,050$ & 0,044 & 0,162 & 0,070 & $-0,023$ & 1,000 & & & & - & 1,19 \\
\hline PAST PERF & 0,135 & 0,154 & 0,000 & $-0,144$ & $-0,071$ & $-0,055$ & $-0,020$ & 1,000 & & & 1,10 & 1,15 \\
\hline LEV & $-0,0286$ & $-0,100$ & 0,092 & 0,312 & 0,017 & 0,020 & $-0,114$ & 0,010 & 1,000 & & 1,25 & 1,32 \\
\hline SIZE & 0,100 & $-0,106$ & 0,056 & 0,328 & 0,026 & 0,005 & 0,298 & $-0,182$ & 0,258 & 1,000 & 1,34 & 1,45 \\
\hline
\end{tabular}

Table 8: Econometric Tests

\begin{tabular}{|c|c|c|c|c|}
\hline \multirow{2}{*}{$\begin{array}{l}\text { Econometric tests } \\
\text { Specification test: }\end{array}$} & \multicolumn{2}{|l|}{ Model 1} & \multicolumn{2}{|l|}{ Model 2} \\
\hline & & & & \\
\hline \multirow{2}{*}{-Hausman test } & Chi2 & prob $>$ Chi-S & Chi2 & prob $>$ Chi-S \\
\hline & 20,12 & 0,0053 & 25,99 & 0,0038 \\
\hline \multirow[t]{2}{*}{ Test for the presence of individual effects: } & Fisher & prob $>F$ & Fisher & prob $>F$ \\
\hline & 12,84 & 0 & 12,19 & 0 \\
\hline \multicolumn{5}{|l|}{ Heteroskedasticity tests: } \\
\hline \multirow{2}{*}{-Breusch-Pagan test } & Chi2 & prob $>$ Chi-S & Chi2 & prob $>$ Chi-S \\
\hline & 38,69 & 0 & 69,78 & 0 \\
\hline \multirow{2}{*}{-Modified Wald test } & Chi2 & prob $>$ Chi-S & Chi2 & prob $>$ Chi-S \\
\hline & $1,20 \mathrm{E}+05$ & 0 & $1,94 \mathrm{E}+04$ & 0 \\
\hline \multicolumn{5}{|l|}{ Tests for autocorrelation of the errors: } \\
\hline \multirow{2}{*}{-Wooldridge test } & Fisher & prob $>F$ & Fisher & prob $>F$ \\
\hline & 9,015 & 0,5 & 8,861 & 0,53 \\
\hline -Pesaran test & 1,452 & 0,1464 & 1,338 & 0,181 \\
\hline
\end{tabular}


Table 9: Regression Results

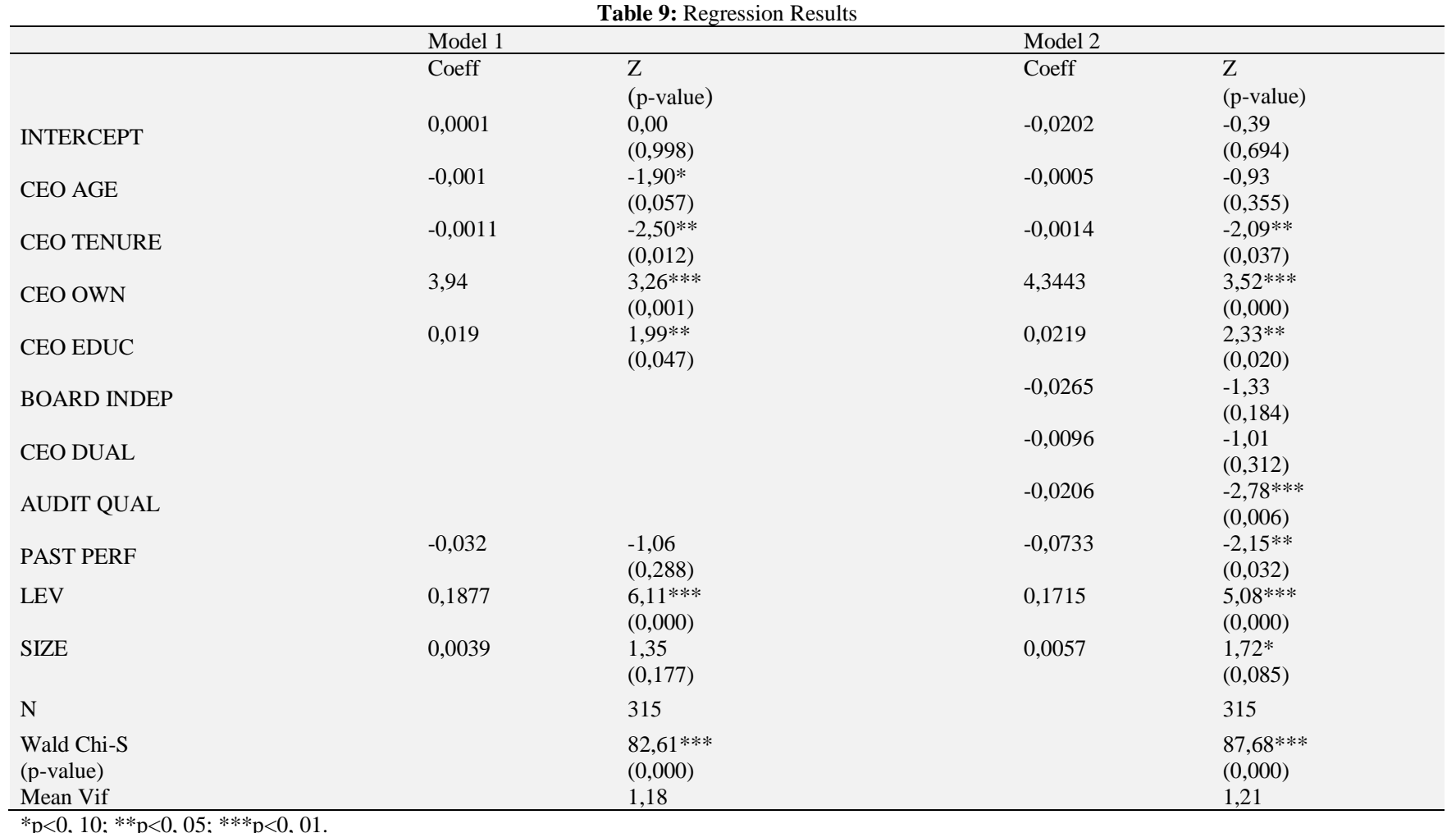

${ }^{*} \mathrm{p}<0,10 ; * * \mathrm{p}<0,05 ; * * * \mathrm{p}<0,01$

As shown in table 7, all correlation coefficients are less than 0,4. To detect the potential problem of multicollinearity, we check also the variance inflation factor for each independent variable. Table 7 reveals that the highest VIF value is 1,45 ; which suggests that multicollinearity is not likely to present an issue in this analysis.

In order to choose the best estimation method for the multivariate analysis, it is imperative to follow the order of certain econometric steps which are presented in table 8 .

The results of the Hausman test for models 1 and 2 show a ChiSquare statistically significant at the $1 \%$ level, suggesting that the random-effects model may not be suitable for the present data; while the fixed-effects model is the appropriate approach for this case. We also find that the test for the presence of specific fixed effect provides a significant Fisher statistic test. So, the hypothesis of homogeneity of observations of the model is rejected. Consequently, the panel structure could be retained for models 1 and 2 .

To detect the heteroskedasticity problems, the results of the Breusch-Pagan and Modified Wald tests should be examined for each model. The results of the Breusch-Pagan test show a significant Chi-Square statistic at the $1 \%$ level. Then, it exists an intraindividual heteroskedasticity problem for models 1 and 2. Similarly, the results of the modified Wald test reveal a significant ChiSquare statistic at the $1 \%$ level. So, it exists also an interindividual heteroskedasticity problem for the two models.

Finally, the results of the Wooldridge and Pesaran tests are examined to verify the absence of correlation between residues. The table 8 shows a non-significant Fisher test, so there is an absence of an intra-individual autocorrelation problem. Furthermore, the probability of the Pesaran test is not significant. So, there is an absence of an inter-individual autocorrelation problem.

Then, it is adequate to estimate the two models using the Generalized Least Squares (GLS) method using variants of the STATA function "xtgls" which allows to combine the conclusions of the tests performed and to correct the observed problems.

Table 9 reports the regression results of the GLS method.

Wald test suggests that models 1 and 2 fitted the data significantly. Indeed, the Wald Chi-S global significance test presented in this table is significant at the level of $1 \%$ (Prob $>$ Chi-S $=0.000$ ) for models 1 and 2 . In this case, the null hypothesis of non-fit model to the data is rejected. Then, models 1 and 2 are adapted significantly to the panel data.
CEO characteristics have significant coefficients in models 1 and 2 and provide supportive evidence for developed hypotheses.

Hypothesis 1 argues the existence of negative relationship between the R\&D capitalization and the CEO age. As shown in table 9, the coefficient of the CEO age is negative and significant at the $10 \%$ level for model 1 . Younger manager aims to transmit signals to the labor market relating to his management quality, personal skills and innovation capacities by capitalizing $R \& D$ expenditures. However, after the integration of corporate governance variables in the model 2, the coefficient of CEO age becomes not statistically significant. Therefore, Hypothesis 1 receives marginal support. Hypothesis 2 proposes the existence of negative relationship between the R\&D capitalization and the CEO tenure. Findings in model 1 provide support for this hypothesis. Indeed, the manager tenure has a negative and significant effect on the R\&D capitalization at the 5\% level. A manager, at the beginning of his career in the firm, tries to show his interests for innovation and creativity by the R\&D capitalization. When he maintains his position for a long time, the manager favors an increase in information asymmetry by expensing R\&D investments. However, by comparing magnitude of coefficients in model 2 (integrating the corporate governance variables) with those of model 1 , it is clear that the integration of the corporate governance variables limits slightly the impact of manager tenure on the $\mathrm{R} \& \mathrm{D}$ capitalization.

Hypothesis 3 argues the existence of positive relationship between the R\&D capitalization and the CEO ownership. Findings in model 1 provide supportive evidence for hypothesis 3 . Indeed, the manager ownership has a positive and significant effect on the R\&D capitalization at the $1 \%$ level. A possible explanation to these findings here is that the manager prefers accounting policies that maximize the company's short-term earnings, because he holds his shares over a short period. The positive impact of CEO ownership is confirmed also in model 2 . However, it is clear that the integration of corporate governance variables amplifies the impact of CEO ownership on the R\&D capitalization.

Hypothesis 4 proposes the existence of positive relationship between the R\&D capitalization and the CEO education in a prestigious institution. Findings in model 1 provide support for this hypothesis. Indeed, the CEO education has a positive and significant effect on the R\&D capitalization at the $5 \%$ level. A possible explanation of these findings here is that a manager, former student of a prestigious institution has a real concern to keep the good 
reputation on his training and capacities to carry out complex and innovative activities such as $\mathrm{R} \& \mathrm{D}$. Then, this manager privileges the disclosure of his efforts in innovation by the R\&D capitalization. The positive impact of CEO education is confirmed also in model 2. However, it is clear that the integration of corporate governance variables amplifies the impact of CEO education on the R\&D capitalization.

Regarding the impact of corporate governance variables, only external audit quality has significant effect on R\&D capitalization. However, this result doesn't support the hypothesis 7 which stipulates a positive relationship between the $R \& D$ capitalization and the external audit quality. Findings in model 2 are consistent with those of Chi and Weng (2014) who confirm that big 4 auditors recommend to their clients more prudent accounting choices.

Finally, some control variables produce interesting results.

Past performance has a negative and significant influence on the R\&D capitalization at the $5 \%$ level in the model 2. A possible explanation of the findings here is that a manager is encouraged to increase the R\&D capitalization in the case of low past performance to signal to the shareholders a good future performance of the company.

Leverage has a positive and significant effect on the R\&D capitalization at the $1 \%$ level in the models 1 and 2 . A possible explanation of the findings here is that many firms capitalize $R \& D$ investments to move away from the limits set in debt covenants and to take advantage of other financial debts.

Firm size has a positive and significant effect on the R\&D capitalization at $10 \%$ level in the model 2 . This result could be explained by the capacity of big firms to satisfy some R\&D capitalization conditions.

\section{Conclusions}

This study explores the R\&D capitalization determinants for a sample of French listed companies. It offers new research insight for the managerial and accounting literature by investigating the CEO characteristics' role on $R \& D$ financial accounting report. It suggests that CEO characteristics and corporate governance variables could be considered in the study of R\&D capitalization determinants. The findings confirm that CEO characteristics are relevant factors of $R \& D$ capitalization decision. Specifically, the results show that CEO ownership, age, tenure and education; audit quality; past performance; leverage and size are significantly associated with R\&D capitalization. Even after the introduction of governance variables, the CEO characteristics maintain their significant effects except the case of CEO age; and in some cases these effects become more significant.

This study contributes to the financial reporting and corporate governance literature by providing empirical evidence for the existence of significant effects of CEO characteristics and audit quality on R\&D capitalization. Also, this research offers meaningful implications for accounting standard setters. Indeed, the empirical results contribute to the continuing debate surrounding the R\&D accounting treatment between US GAAP and IFRS. While giving managers the possibility of capitalizing $R \& D$ expenditures enhances the accounting information quality, the findings suggest that R\&D capitalization decision is closely related with the CEO characteristics. Then, this research offers supportive evidence to the R\&D accounting treatment under US GAAP. These findings are also consistent with the idea that $\mathrm{R} \& \mathrm{D}$ capitalization, according to IAS 38 , does not reduce information asymmetry but even increase analysts' forecast errors (Thi \& Schultze 2014).

Future research may investigate other manager variables to explain the R\&D accounting treatment decision. The CEO remuneration could be a potential issue in the study of $R \& D$ accounting treatment determinants. Also, it is interesting to evaluate the internal audit effects on R\&D accounting treatment. Finally, there is a possible extension of this research to other European countries requiring companies to prepare their annual reports in accordance with IAS/IFRS

\section{References}

[1] Abdoli, M. R. \& Royaee, R. (2012) 'Board monitoring and earnings quality: an empirical study in Iran', African Journal of Business Management, Vol. 6 No. 11, pp.4179-4184.

[2] Aboody, D \& Lev, B. (1998) 'the value relevance of intangibles: the case of software capitalization', Journal of Accounting Research, Vol. 36 No. supplement, pp.161-191. https://doi.org/10.2307/2491312.

[3] Anderson, R. C., Mansi, S., \& Reeb, D. M. (2004) 'Board characteristics, accounting report integrity, and the cost of debt', Journal of Accounting \& Economics, Vol. 37 No. 3, pp.315-342. https://doi.org/10.1016/j.jacceco.2004.01.004.

[4] Anwer S. A. \& Scott, D. (2013) 'Managerial Overconfidence and Accounting Conservatism', Journal of Accounting Research, Vol. 51 No. 1, pp.1-30. https://doi.org/10.1111/j.1475679X.2012.00467.x.

[5] Ali, A. \& Zhang, W. (2015) 'CEO Tenure and Earnings Management', Journal of Accounting and Economics, Vol. 59 No. 1, pp.160-79. https://doi.org/10.1016/i.jacceco.2014.11.004

[6] Arcay, M.R.B. \& Vázquez, M.F.M. (2005) 'Corporate characteristics governance rules and the extent of voluntary disclosure in Spain', Advances in Accounting, Vol. 21 No. 1, pp. 299-331. https://doi.org/10.1016/S0882-6110(05)21013-1.

[7] Banal-Estañol, A. \& Macho-Stadler, I. (2010) 'Scientific and Commercial Incentives in R\&D: Research versus Development?', Journal of Economics \& Management Strategy, Vol.19 No. 1, pp.185-221. https://doi.org/10.1111/j.1530-9134.2009.00250.x.

[8] Barker, V.L. \& Mueller, G.C. (2002) 'CEO characteristic and firm R\&D spending', Management Science, Vol. 48 No. 6, pp.782-801. https://doi.org/10.1287/mnsc.48.6.782.187.

[9] Benali, A. (2013) 'The Shareholders Confidence and Effectiveness of the Joint Auditors: Empirical Validation in the French Context', International Journal of Business and Management, Vol. 8 No.11, pp.76-84. https://doi.org/10.5539/ijbm.v8n11p76.

[10] Ben Othman, H. \& Zéghal, D. (2006) 'A Study of Earnings Management Motives in the Anglo-American and Euro-Continental Accounting Models: The Candian and French Cases', The International Journal of Accounting, Vol. 41 No. 4, pp.406-435. https://doi.org/10.1016/j.intacc.2006.09.004.

[11] Bertin, E. (2002) 'formation à l'audit: déterminants, contenu et voies de recherche'. Paper presented at $23^{\text {th }}$ Congress of AFC (Association Française de Comptabilité) May 2002, Toulouse.

[12] Bétriou J.L. \& Vignolles M. (1990) 'Influence des options en consolidation sur la présentation des comptes', Revue Fiduciaire Comptable, Vol. 154 No. 6, pp.23-28.

[13] Bourmont, M. (2006) 'Les déterminants de la publication d'informations sur les activités de recherche et développement en France: une étude longitudinale et méthodologique'. Paper presented at $27^{\text {th }}$ Congress of AFC (Association Française de Comptabilité). May 2006, Tunisie.

[14] Cazavan-Jeny, A., Jeanjean, T. \& Joos, P. (2011) 'Accounting choice and future performance: The case of $R \& D$ accounting in France', Journal of accounting and public policy, Vol. 30 No. 2, pp.145-165. https://doi.org/10.1016/j.jaccpubpol.2010.09.016.

[15] Chambers, D.J., Jennings, R. \& Thompson, R.B. (2003) 'Managerial Discretion and Accounting for Research and Development Costs', Journal of Accounting, Auditing and Finance, Vol. 18 No. 1, pp.79113. https://doi.org/10.1177/0148558X0301800105

[16] Chen, H.L. \& Hsu, W. T. (2009) 'Family ownership, board independence and R\&D investment', Family Business Review, Vol. 22 No. 4, pp.347-362. https://doi.org/10.1177/0894486509341062.

[17] Chi, H.Y. \& Weng, T.C. (2014) 'Managerial legal liability and Big 4 auditor choice', Journal of Business Research, Vol. 67 No. 9, pp.1857-1869. https://doi.org/10.1016/j.jbusres.2013.12.003.

[18] Chi, W., Liu, C. \& Wang, T. (2009) 'what affects accounting conservatism: A corporate governance perspective', Journal of Contemporary Accounting \& Economics, Vol. 5 No. 1, pp.47-59. https://doi.org/10.1016/j.jcae.2009.06.001.

[19] Chikh, S. \& Filbiena, J. Y. (2011) 'Acquisitions and CEO power: Evidence from French networks', Journal of Corporate Finance, Vol 17 No. 1, pp.1221-1236. https://doi.org/10.1016/j.jcorpfin.2011.06.007.

[20] Cormier, D., Magnan, M. \& Morard, B. (1998) 'La gestion stratégique de résultats: le modèle anglo-saxon convient-il au contexte Suisse ?', Comptabilité Contrôle Audit, Vol. 1 No. 3, pp.25-48. https://doi.org/10.3917/cca.041.0025. 
[21] Dameron, S. (2008) 'La Généalogie des Nouveaux Dirigeants', In Le Nouveau Visage des Dirigeants du CAC40, Chapter 1, pp.7-16. Paris: Pearson Edition.

[22] De Fond, M. \& Jiambalvo, J. (1994) 'Debt covenant violation and manipulation of accruals', Journal of Accounting and Economics, Vol. 17 No 1-2, pp.145-176. https://doi.org/10.1016/01654101(94)90008-6.

[23] Dong, J. \& Gou, Y. N. (2010) 'Corporate governance structure, managerial discretion and the R\&D investment in China', International Review of Economies and Finance, Vol. 19 No. 2, pp.180188. https://doi.org/10.1016/j.iref.2009.10.001

[24] Dimitropoulos, P. \& Asteriou, D. (2010) 'the effect of board composition on the informativeness and quality of annual earnings: empirical evidence from Greece', Research in International Business and Finance, Vol. 24 No. 2, pp.190-205. https://doi.org/10.1016/j.ribaf.2009.12.001

[25] Dinh, T., Kang, H. \& Schultze, W. (2016) 'Capitalizing Research \& Development: Signaling or Earnings Management?' European Accounting Review, Vol. 25 No. 2, pp.373-401. https://doi.org/10.1080/09638180.2015.1031149.

[26] Dumas, G. (2013) 'Gestion processuelle des résultats: Une étude pré- et post-IFRS des dépenses de R\&D des entreprises françaises cotées', Paper presented at $34^{\text {th }}$ Congress of AFC (Association Française de Comptabilité), May, 2013 Montréal.

[27] El aouadi, A. (2001) 'Les stratégies d'enracinement des dirigeants d'entreprise : le cas marocain', Working paper $n^{\circ} 599$ CEROG, IAE d'Aix-Marseille, May, 2001.

[28] Finkelstein, S. (1992) 'Power in top management teams: dimensions, measurement, and validation', Academy of Management Journal, Vol. 35 No. 3, pp. 505-538. https://doi.org/10.2307/256485.

[29] Firth, M., Fung, P. M.Y., \& Rui, O. M. (2007) 'Ownership, two-tier board structure, and the informativeness of earnings-evidence from China', Journal of Accounting and Public Policy, Vol. 26 No. 4, pp. 463-496. https://doi.org/10.1016/j.jaccpubpol.2007.05.004.

[30] Forker, J. (1992) 'Corporate governance and disclosure quality', Accounting and Business Research, Vol. 22 No. 86, pp.111-124. https://doi.org/10.1080/00014788.1992.9729426.

[31] Garcia Lara, J.M., Garcia Osma, B. \& Penalva, F. (2009) 'Accounting conservatism and corporate governance', Review of Accounting Studies, Vol. 14 No. 1, pp.161-201. https://doi.org/10.1007/s11142007-9060-1.

[32] General Accounting Plan (1999) 'Règles et méthodes relatives aux comptes consolidés', Order of 22 June 1999 approving Regulation 99-02 du CRC, KPMG, Économica, 24 pages.

[33] Ghosh, A., Moon, D. \& Tandon, K. (2007) 'CEO ownership and discretionary investments', Journal of Business Finance \& Accounting, Vol. 34 No. 5-6, pp.819-839. https://doi.org/10.1111/j.1468-5957.2007.02011.x.

[34] Gul, F.A. \& Leung, S. (2004) 'Board Leadership, Outside Directors' Expertise and Voluntary Corporate Disclosures', Journal of Accounting and public Policy, Vol. 23 No. 5, pp.351-379. https://doi.org/10.1016/j.jaccpubpol.2004.07.001.

[35] Healy, P.M., Myers, S.C. \& Howe, C.D. (2002) 'R\&D Accounting and the Trade-off Between Relevance and Objectivity', Journal of Accounting Research, Vol. 40 No. 3, pp.677-710. https://doi.org/10.1111/1475-679X.00067.

[36] Ho, S. S. M. \& Wong, K. S. (2001) 'A study of corporate disclosure practice and effectiveness in Hong Kong', Journal of International Financial Management and Accounting, Vol. 12 No. 1, pp.75-102. https://doi.org/10.1111/1467-646X.00067.

[37] Holtz, L. \& Neto, A. S. (2014) 'Effects of Board of Directors' Characteristics on the Quality of Accounting Information in Brazil', Revista Contabilidade \& Finanças, Vol. 25 No. 66, pp.255-266. https://doi.org/10.1590/1808-057x201412010.

[38] Huang, H.W., Rose-Green, E. \& Lee, C. C. (2012) 'CEO Age and Financial Reporting Quality', Accounting Horizons, Vol. 26 No. 4, pp.725-740. https://doi.org/10.2308/acch-50268.

[39] IASB (2009) 'IAS 38 (revised): Intangible Assets', London, available at: http://www.ifrs.org.

[40] Jedidi Hentati, E. \& Jilani, F. (2013) 'The determinants of nonaudit fees in French firms', Management Science Letters, Vol. 3 No.3, pp.1773-1782. https://doi.org/10.5267/j.msl.2013.05.004

[41] Jensen, M. C. \& Murphy, K. J. (2010) 'CEO Incentives-It's Not How Much You Pay, But How', Journal of Applied Corporate Finance, Vol. 22 No.1, pp. 64-76. https://doi.org/10.1111/j.17456622.2010.00262.x.

[42] Kamarudin, K.A., Ismaila, W. A. I. \& Samsuddina, M. E. (2012) 'The Influence of CEO Duality on the Relationship between Audit Committee Independence and Earnings Quality', Procedia-Social and Behavioral Sciences, Vol. 65 No. 3, pp.919-924. https://doi.org/10.1016/j.sbspro.2012.11.220.

[43] Kim K., E., Mauldin, S. \& Patro, S. (2014) 'Outside directors and board advising and monitoring performance', Journal of Accounting and Economics, Vol. 57 No.2-3, pp.110-131. https://doi.org/10.1016/j.jacceco.2014.02.001.

[44] Klein, A. (2002) 'Audit Committee, Board of Director Characteristics, and Earnings Management', Journal of Accounting and Economics, Vol. 33 No.2-3, pp.375-400. https://doi.org/10.1016/S0165-4101(02)00059-9.

[45] Koh, P. S., David M. \& Zhao, R. W. (2015) 'Forcing Managers to Talk: CEO Confidence and R\&D Opacity', Working paper, available at:

http://www.davidreeb.net/uploads/4/8/0/7/48079951/forcing_mana gers_to_talk_4-29.pdf.

[46] Landry, S. \& Callimaci, A. (2003) 'The effect of management incentives and cross-listing status on the accounting treatment of R\&D spending', Journal of International Auditing and Taxation, Vol. 12 No. 2, pp.131-152. https://doi.org/10.1016/j.intaccaudtax.2003.08.003.

[47] Lara, J. M. G., Osma, B. G. \& Penalva, F. (2007) 'Board of directors' characteristics and conditional accounting conservatism: Spanish evidence', European Accounting Review, Vol. 16 No. 4, pp.727755. https://doi.org/10.1080/09638180701706922.

[48] Liao, C. H. (2011) 'The effect of stock-based incentives and governance mechanisms on voluntary disclosure of intangibles', $A d$ vances in Accounting, Vol. 27 No. 2, pp.294-307. https://doi.org/10.1016/j.adiac.2011.04.002.

[49] Markarian,G., Pozza, L. \& Prencipe, A. (2008) 'Capitalization of R\&D costs and earnings management: Evidence from Italian listed companies', The International Journal of Accounting, Vol. 43 No. 3, pp.246-267. https://doi.org/10.1016/j.intacc.2008.06.002.

[50] Marra A., Mazzola, P., \& Prencipe, A. (2011) 'Board monitoring and earnings management pre- and post-IFRS', The International Journal of Accounting, Vol. 46 No. 2, pp. 205-230. https://doi.org/10.1016/j.intacc.2011.04.007.

[51] Matsunaga, S. R. \& Yeung, P. E. (2008) 'Evidence on the Impact of a CEO's Financial Experience on the Quality of the Firm's Financial Reports and Disclosures', AAA 2008 Financial Accounting and Reporting Section (FARS), SSRN electronic journal, available at: https://doi.org/10.2139/ssrn.1014097.

[52] Miller, K. D. \& Bromiley, P. (1990) 'Strategic Risk and Corporate Performance: An Analysis of Alternative Risk Measures', Academy of Management Journal, Vol. 33 No. 4, pp. 756-779. https://doi.org/10.2307/256289.

[53] Mouline, J.P. (2000) 'Dynamique de la succession managériale dans la PME familiale non cotée', Finance Contrôle Stratégie, Vol.3 No.1, pp.197-222.

[54] Murphy, T., O'Connell, V. \& Ohogartaigh, C. (2013) 'Discourses surrounding the evolution of the IASB/FASB Conceptual Framework: What they reveal about the "living law" of accounting', $A c$ counting, Organizations and Society, Vol. 38 No. 1, pp.72-91. https://doi.org/10.1016/j.aos.2012.07.003.

[55] Nekhili, M. \& Fakhfakh, I. (2006) 'les relations entre les mécanismes de gouvernement et l'indice de divulgation volontaire d'informations : étude clinique de deux entreprises Tunisiennes'. Paper presented at $27^{\text {th }}$ Congress of AFC (Association Française de Comptabilité). May 2006, Tunis.

[56] Nekhili, M. \& Poincelot, E. (2000) 'La fonction R\&D et la latitude managériale : Une analyse théorique', Finance-Contrôle-Stratégie, Vol. 3 No. 1, pp.5-28.

[57] Nekhili, M. \& Rebai Azouz, S. (2006) 'Investissement en R\&D, mode de comptabilisation et gestion des résultats', Gestion 2000, Vol. 23 No. 6, pp.15-34.

[58] Nekhili, M., Hussainey, K., Cheffi, W., Chtioui, T. \& Tchakoutetchuigoua, H. (2016) 'R\&D narrative disclosure, corporate governance and market value: Evidence from France', Journal of Applied Business Research, Vol 32 No. 1, pp.111-138. https://doi.org/10.19030/jabr.v32i1.9527.

[59] Nor, H. M., Saleh, N. M., Jaffar, R. \& Shukor, Z. A. (2010) 'Corporate Governance and R\&D Reporting in Malaysian MESDAQ Market', Int. Journal of Economics and Management, Vol 4 No. 2, pp. 350-372.

[60] Oswald, D. R. (2008) 'The determinants and value relevance of the choice of accounting for research and development expenditures in the United Kingdom', Journal of Business Finance \& Accounting, Vol 35 No. 1-2, pp.1-24. https://doi.org/10.1111/j.14685957.2007.02060.x.

[61] Paquerot, M. (1997) 'Stratégies d'enracinement des dirigeants, performance de la firme et structure de contrôle', pp. 105-138/ Chapter 
of the collective book, under the direction of Charreaux G. : Le gouvernement de l'entreprise, Théories et faits», Économica, ISBN: 9782717832532, 540 pages.

[62] Percy, M. (2000) 'Financial reporting discretion and voluntary disclosure corporate research and development expenditure in Australia', Asian Pacific Journal of Accounting \& Economics, Vol. 7 No. 1, pp.1-31. https://doi.org/10.1080/16081625.2000.10510572.

[63] Pigé, B. (1998) 'Enracinement des dirigeants et richesse des actionnaires', Finance-Contrôle-Stratégie, Vol. 1 No. 3, pp.131-158.

[64] PricewaterhouseCoopers (2010) 'Accounting for innovation: The impact on technology companies of accounting for R\&D activity under IFRS', Available at:

https://www.pwc.com/us/en/issues/ifrs-reporting/assets/ifrs-technologyaccounting-r-d.pdf.

[65] Schrand, C. M. \& Zechman, S. L. C. (2012) 'Executive overconfidence and the slippery slope to financial misreporting', Journal of Accounting and Economics, Vol. 53 No. 1-2, pp.311-329. https://doi.org/10.1016/j.jacceco.2011.09.001.

[66] Rebai Azouz, S. (2011) 'Les motivations de l'inscription des investissements en R\&D à l'actif: divulgation volontaire d'informations ou gestion des résultats?', Paper presented at $32^{\text {th }}$ Congress of AFC (Association Française de Comptabilité), May, 2011, Montpellier.

[67] Sundaram, R. K. \& Yermack, D. L. (2007) 'Pay Me Later: Inside Debt and Its Role in Managerial Compensation', Journal of $\mathrm{Fi}$ nance, Vol. 62 No. 4, pp.1551-1588. https://doi.org/10.1111/j.15406261.2007.01251.x.

[68] Thi, T. \& Shultze, W. (2014) 'Capitalizing research and development $(\mathrm{R} \& \mathrm{D})$ expenditures-Do the perceived benefits materialize in practical application?' Working paper, University of New South Wales, Available at:

https://www.researchgate.net/publication/266462344_Capitalizing_ research_and_development_RD_expenditures.

[69] Triki Damak, S. \& Halioui, K. (2013) 'Accounting treatment of R\&D expenditures and earnings management: an empirical study on French listed companies', Global Business and Economics Research Journal, Vol. 2 No. 1, pp.50-71.

[70] Triki Damak, S. \& Halioui, K. (2016) 'R\&D investment, management entrenchment and governance mechanisms: evidence from French listed companies on SFB120 index', Int. J. Accounting and Finance, Vol. 6, No. 3, pp. 197-218. https://doi.org/10.1504/IJAF.2016.081700

[71] Tutticci I., Krishnan G. \& Percy M. (2007) 'the role of externa monitoring in firm valuation: The case of R\&D capitalisation', Journal of International Accounting Research, Vol. 6, No. 2, pp. 83-107. https://doi.org/10.2308/jiar.2007.6.2.83.

[72] Vernimmen, P., Quiry, P. \& Fur, Y.L. (2014) 'Finance d'entreprise', Dalloz, ISBN: 9782247129751, 1201 pages.

[73] Warfield, T.D., Wild, J.J. \& Wild, K.L. (1995) 'Managerial ownership, accounting choices, and informativeness of earnings', Journal of Accounting and Economics, Vol. 20 No. 1, pp.61-91. https://doi.org/10.1016/0165-4101(94)00393-J.

[74] Williams, L. J. \& Hazer, J. T. (1986) 'Antecedents and consequences of satisfaction and commitment in turnover models: A reanalysis using latent variable structural equation methods', Journal of Applied Psychology, Vol. 71 No. 2, pp.219-232. https://doi.org/10.1037/0021-9010.71.2.219.

[75] Wu, J. \& Tu, R. (2007) 'CEO stock option pay and R\&D spending: a behavioral agency explanation', Journal of Business Research, Vol. 60 No. 5, pp.482-492. https://doi.org/10.1016/j.jbusres.2006.12.006

[76] Zhao, R. (2002) 'Relative Value Relevance of R\&D Reporting: An International Comparison', Journal of International Financial Management and Accounting, Vol. 13 No. 2, pp.153-172. https://doi.org/10.1111/1467-646X.00082.

[77] Zéghal, D., Mouelhi, R. \& Louati, H. (2007) 'An analysis of the determinants of R\&D voluntary disclosure by Canadian firms', The Irish Accounting Review, Vol. 14 No. 2, pp.61-89. 